\title{
LEGUMES AND GRASSES FOR DRY NORTH CANTERBURY HILL COUNTRY
}

\author{
J. G. H. White, G. MeiJer \\ Plant Science Deparfmenf, Lincoln College
}

\begin{abstract}
Abstrac!
Field experiments have been conducted for 6 years at Hunua in North Canterbury to compare a range of grass and legume cultivars for sunny aspects of dry hill country. The most suitable legumes were Woogenellup subterranean clover and College Glutinosa lucerne. White, red and alsike clovers, Lotus corniculatus and $L$. pedunculatus did not survive summer droughts, while Trifolium ambiguum was low producing. Of the grasses, Grasslands K1950 cocksfoot showed promise, being drought resistant, coal season active and easily established from ovcrsowing. Perennial ryegrasses, Grasslands Apanui cocksfoot and Grasslands 4710 tall fescue did not tolerate severe droughts. Recommendations are given for establishment and management of the most promising species for this environment.
\end{abstract}

\section{INTRODUCTION}

The Lincoln College hill country property of "Hunua" is typical of large areas of dry hill country in North Canterbury, and in Marlborough and North Otago. The mean annual rainfall is $660 \mathrm{~mm}$ but is highly variable and in the $\mathbf{1 2}$ years of records has ranged from 432 to $\mathbf{9 1 5} \mathrm{mm}$. Droughts are normal in summer but may extend into spring or autumn, while winters are cool and frosty. The climate is dominated by strong prevailing north-west winds which produce marked contrasts between sunny and shady aspects. On sunny aspects active plant growth is restricted to spring and autumn, while on shady faces pasture growth continues further into summer.

There is generally little problem in improving shady aspects. Initial experiments (White et al., 1972) showed that white clover (Trifolium repens) is easily established and maintained by rotational grazing, while grasses such as Ruanui ryegrass (Lolium perenne) can be established after 3 years of clover, when the soil fertility has been raised.

On sunny slopes, however, perennial clovers do not appear to survive a severe summer drought except in damper 'sites or in the shelter of tussock or matagouri. Early work (White, 1970) showed that lucerne (Medicago glufinosa) could be established 
from oversowing on northerly aspects, but no large-scale sowing was attempted. Of the grasses suitable for sunny slopes, Currie cocksfoot (Dactylis glomerata) appeared most promising (White et al., 1972) .

Because of the uncertainty about which are the most suitable legumes and grasses for sunny aspects, our recent experiments have concentrated on species introduction and testing for this particular environment. The Hunua trial site was located on a Huruni hill soil with a $\mathrm{pH}$ of 5.6, deficient in sulphur, and with a moderate available phosphorus level (Olsen $\mathrm{P}=18$ ) . The vegetation was largely darithonia (Notodanthonia spp.) and blue wheat grass (A gropyron scabrum), with some low-producing annual clovers and much bare ground. Scattered tussock (Poa laevis) and matagouri (Discaria toumatou) were also present.

The Coopers Creek site near Oxford (Radcliffe et al., 1977) was also on a Hurunui soil, but the mean annual rainfall was $1450 \mathrm{~mm}$, while the vegetation was dominantly browntop (Agrostis tenuis) .

\section{Grasses}

Experiments were established in 1973 at Hunua and Coopers Creek to evaluate the survival and growth of seven grass cultivars. Using the tubeling technique (Radcliffe et al., 1977), seedlings were planted into the resident vegetation in early September, after removing cores of soil of the same dimensions as the tubes containing the seedling and potting mix. The plots were single rows $60 \mathrm{~cm}$ apart containing 10 plants at spaces of $15 \mathrm{~cm}$. The trial was a factorial design with three nitrogen fertilizer treatments $(0$, 25 , and $100 \mathrm{~kg} / \mathrm{ha} \mathrm{N}$ as urea), and replicated five times. All plots received molybdic superphosphate at $500 \mathrm{~kg} / \mathrm{ha}$ at sowing, while nitrogen applications were split and applied in early and late spring, and in autumn. All plots were grazed periodically with sheep for intervals of 1 to 2 days.

All cultivars established well at both sites, and in early December 1973 over $90 \%$ were present. The next 2 months were dry at Hunua and considerable plant mortality occurred, but survival at Coopers Creek was much superior because of the higher rainfall. Although nitrogen treatments increased growth of resident grasses, there was little effect on survival and growth of the introduced species. Table 1 shows grass survival at the two sites.

These results confirmed that, at Hunua, survival of all ryegrasses is poor on sunny aspects, and that Currie and K1950 are 
TABLE 1: PERCENTAGE SURVIVAL OF SEVEN GRASSES ON SUNNY SLOPES, 14 MONTHS FROM ESTABLISHMENT

\begin{tabular}{|c|c|c|}
\hline & Hunua & Coopers Creek \\
\hline \multicolumn{3}{|l|}{ Cultivar } \\
\hline $\begin{array}{l}\text { Grasslands Ruanui ryegrass } \\
\text { (Lolium perenne) }\end{array}$ & $2 \mathrm{~d}$ & $36 \mathrm{~b}$ \\
\hline Grasslands Nui ryegrass & $11 \mathrm{c}$ & $48 \mathrm{~b}$ \\
\hline Medea ryegrass (S. Australia) & $13 \mathrm{c}$ & $9 \mathrm{c}$ \\
\hline $\begin{array}{l}\text { Grasslands Apanui cocksfoot } \\
\text { (Dactylis glomerata) }\end{array}$ & $22 \mathrm{~b}$ & 79 a \\
\hline Grasslands K1950 cocksfoot & 43 a & $82 \mathrm{a}$ \\
\hline Currie cocksfoot (W. Australia) & $51 \mathrm{a}$ & $67 \mathrm{a}$ \\
\hline $\begin{array}{l}\text { Grasslands } 4710 \text { tall fescue } \\
\text { (Festuca arundinacea) }\end{array}$ & $2 d$ & $17 \mathrm{c}$ \\
\hline Rainfall, Sep '73-Aug '74 (mm) & 739 & 1293 \\
\hline
\end{tabular}

better than the standard Apanui cocksfoot. However, K1950 was more vigorous than Currie and is recommended when seed becomes available. At the wetter site of Coopers Creek, Ruanui and Nui ryegrasses and Apanui cocksfoot survived much better than at Hunua, while Australian introductions did not compete well with the resident browntop.

\section{LEGUMES}

A trial to examine the survival and production of five common legumes under 4- or S-week cutting intervals was established at Hunua in April 1974. Plots were $1 \mathrm{~m}^{2}$ in area and contained 49 seedlings planted into short resident vegetation using the tubeling technique. The experiment was a factorial design with four replicates. All plots received a basal dressing of $500 \mathrm{~kg} / \mathrm{ha}$ of molybdic superphosphate at planting. Legume dry matter yields in 1974-5 and 1975-6 and plant survival 12 months from establishment are presented in Table 2.

The 1974-5 season was wetter than average (887 mm JulyJune), with a relatively short summer drought. Consequently the production and survival of white clover was greater than expected, although subterranean clover produced the highest yield. Lucerne took some time to establish and showed the benefit of long spelling for good survival. Both red and alsike clovers were disappointing, and after an initial burst of growth in spring rapidly declined in plant number and production.

In the 1975-6 season, red and alsike clover -plots were too poor to harvest, while white clover yields were reduced owing 
LEGUMES, GRASSES IN HILL COUNTRY

TABLE 2: DRY MATTER YIELDS AND PLANT SURVIVAL OF INTRODUCED LEGUMES

\begin{tabular}{|c|c|c|c|c|c|}
\hline Cultivar & $\begin{array}{l}\text { Cutting } \\
\text { Interval } \\
\text { (weeks) }\end{array}$ & $\begin{array}{l}\text { DM Yield } \\
1974-5 \\
(\mathrm{~kg} / \mathrm{ha})\end{array}$ & $\begin{array}{c}\text { Plant } \\
\text { Survival } \\
\text { at } \\
15.4 .75 \\
(\%)\end{array}$ & $\begin{array}{l}l^{\text {DM Yield }} \\
\quad(\mathrm{kg} / \\
\text { Sep.-Oct. }\end{array}$ & $\begin{array}{l}\text { 1975-6 } \\
\text { Tha) } \\
\text { Total }\end{array}$ \\
\hline $\begin{array}{l}\text { Grasslands Huia white clover } \\
\text { (Trifolium repens) }\end{array}$ & $\begin{array}{l}4 \\
8\end{array}$ & $\begin{array}{l}5700 \mathrm{a} \\
6540 \mathrm{a}\end{array}$ & $\begin{array}{l}53 \\
28\end{array}$ & $\begin{array}{l}197 \mathrm{oc} \\
2470 \mathrm{c}\end{array}$ & $4 \overrightarrow{370}$ \\
\hline $\begin{array}{l}\text { Grasslands Pawera red clover } \\
\text { (T. pratense) }\end{array}$ & $\begin{array}{l}4 \\
8\end{array}$ & $\begin{array}{l}4070 \mathrm{~b} \\
4390 \mathrm{ab}\end{array}$ & $\begin{array}{l}27 \\
29\end{array}$ & $\overline{-}$ & $\bar{z}$ \\
\hline $\begin{array}{l}\text { Alsike clover } \\
\qquad(T . \text { hybridum })\end{array}$ & $\begin{array}{l}4 \\
8\end{array}$ & $\begin{array}{l}252 \mathrm{oc} \\
3960 \mathrm{~b}\end{array}$ & $\begin{array}{c}5 \\
12\end{array}$ & $\overline{-}$ & I \\
\hline $\begin{array}{l}\text { College Glutinosa lucerne } \\
\text { (Medicago glutinosa) }\end{array}$ & $\begin{array}{l}4 \\
8\end{array}$ & $\begin{array}{l}137 \mathrm{oc} \\
4910 \mathrm{a}\end{array}$ & $\begin{array}{l}47 \\
93\end{array}$ & $\begin{array}{c}570 \mathrm{e} \\
6540 \mathrm{a}\end{array}$ & $16 \overline{610} \mathrm{a}$ \\
\hline $\begin{array}{l}\text { Woogenellup } \\
\text { subterranean clover } \\
\text { (T. subterraneum) }\end{array}$ & $\begin{array}{l}4 \\
8\end{array}$ & $\begin{array}{c}3480 \mathrm{~b} \mathrm{v} \\
\quad \text { reger } \\
6860 \mathrm{a} \\
\text { reger }\end{array}$ & $\begin{array}{l}\text { v. good } \\
\text { eneration } \\
\text { good } \\
\text { eneration }\end{array}$ & $\begin{array}{l}3430 \mathrm{~b} \\
6970 \mathrm{a}\end{array}$ & $\begin{array}{c}- \\
7610 b\end{array}$ \\
\hline
\end{tabular}

to low plant numbers. Woogenellup subterranean clover showed particularly good early spring production, but this was closely followed by the lucerne. Four-weekly defoliation resulted in a marked decline in yield, particularly in lucerne. The summer of 1975-6 was moist, with $363 \mathrm{~mm}$ of rain falling between October and February (mean, $266 \mathrm{~mm}$ ), causing the lucerne to grow particularly well and produce an outstanding annual yield. Adjacent plots of lucerne in another trial (Jackson, 1977) also yielded highly $(12000 \mathrm{~kg} / \mathrm{ha})$ in the same season. These results indicate that lucerne and subterranean clover are the most promising species for sunny aspects.

Subsequent to this experiment other legumes have been tested at Hunua. In the autumn of 1975, six selections of Caucasian clover (Trifolium ambiguum), a rhizomatous perennial from southern Russia, were established as single plants in comparison with College Glutinosa lucerne. Results were quite disappointing. Caucasian clover produced poorly and became quite dormant in the cool season and the summer drought, in contrast to lucerne which made some growth'right through these periods.

The success of lucerne on these sunny slopes was confirmed by E. W. Vartha and T. J. Fraser of Grasslands Division, DSIR (pers. comm.) . They compared nine overseas ecotypes of Lofus 
corniculatus with the Grasslands cultivar Maku lotus (L. pedunculatus), a Grasslands selection, G4712 lotus (L. pedunc. X cornic.), Pawera red clover and Huia white clover. These were planted at Hunua in the autumn of 1975 and evaluated over the next 3 years. Few plants survived and none matched the excellent growth of lucerne.

\section{LUCERNE CULTIVARS}

The possibility that creeping lucernes could be valuable for grazing in droughty uncultivated country because of their persistence and spreading ability has been suggested from previous work (White, 1970; White et al., 1975). Two experiments were therefore established to compare the standard Wairau (Medicago sativa) with two creeping lucernes, College Glutinosa (M. glutinosa) and a Rambler hybrid ( $M$. glutinosa $\mathrm{x}$ falcata), both selected by the Plant Science Department at Lincoln College. The first trial was established in 1972 on a steep, sunny, tussockcovered slope on the Port Hills near Christchurch. The site, a Takahe/Kiwi hill soil, was acid ( $\mathrm{pH}$ 5.3), and a basal dressing of $3.75 \mathrm{t} / \mathrm{ha}$ lime and $250 \mathrm{~kg} / \mathrm{ha}$ superphosphate was applied before sowing.

The second experiment was established in 1975 at Hunua. A basal dressing of $250 \mathrm{~kg} / \mathrm{ha}$ of sulphur superphosphate was applied to all plots, while half of each plot received 1 t/ha of lime. Plots measured $10 \times 5 \mathrm{~m}$ at the Port Hills site and $10 \times 7.5 \mathrm{~m}$ at Hunua. In both experiments two rates of seeding were used, 3 and $15 \mathrm{~kg} / \mathrm{ha}$ at the Port Hills and 5 and $10 \mathrm{~kg} / \mathrm{ha}$ at Hunua.

The lucerne was established by a similar technique at both sites. Vegztation was sprayed 6 weeks before sowing with a mixture of amitrole (12 I/ha $20 \%$ a.i.) and dalapon $(5.5 \mathrm{~kg} / \mathrm{ha})$. This killed the Notodanthonia and all other grasses and herbs except sorrel (Rumex acetocella), leaving a short dead cover. Tussocks and matagouri were checked but soon recovered. Heav-

TABLE 3: ESTABLISHMENT OF OVERSOWN LUCERNE ON THE PORT HILLS AND HUNUA, AT TWO SOWING RATES (Plants $\left./ \mathrm{m}^{2}\right)$

\begin{tabular}{|c|c|c|c|c|}
\hline \multirow[b]{2}{*}{ Cultivar } & \multicolumn{2}{|c|}{ Port Hills (1 I. 1'0.72) } & \multicolumn{2}{|c|}{ Hunua $(18.10 .75)$} \\
\hline & $3 \mathrm{~kg}$ & $15 \mathrm{~kg}$ & $5 \mathrm{~kg}$ & $10 \mathrm{~kg}$ \\
\hline Wairau & $6.3 \mathrm{c}$ & $22.3 \mathrm{a}$ & $10.0 \mathrm{c}$ & 31.0 a \\
\hline College Glutinosa & $3.1 \mathrm{c}$ & $20.0 \mathrm{ab}$ & $17.5 \mathrm{ab}$ & $34.3 \mathrm{a}$ \\
\hline Rambler hybrid & $1.0 \mathrm{~d}$ & $14.0 \mathrm{~b}$ & $10.3 \mathrm{c}$ & $19.3 \mathrm{~b}$ \\
\hline
\end{tabular}


ily inoculated $\left(10^{4}\right.$ rhizobia/seed $)$, lime pelleted seed was prepared commercially and broadcast in early August. Table 3 shows the early seedling establishment.

All plots were hard grazed with sheep 3 months after oversowing and rotationally grazed subsequently whenever lucerne reached the $1 \%$ flower stage of growth.

Wairau and College Glutinosa established better and showed more vigorous growth than the Rambler hybrid. No response to lime occurred at Hunua, which confirmed earlier work on a Haldon soil (White, 1970). It soon became obvious that the high sowing rate produced a much better plant cover, and this difference persisted for the next 3 years. Table 4 shows scores for ground cover at the two sites.

TABLE 4: GROUND COVER SCORE OF OVERSOWN LUCERNE ON THE PORT HILLS AND HUNUA AT TWO SOWING RATES $(1=$ poor, $10=$ excellent $)$

\begin{tabular}{|c|c|c|c|c|}
\hline & \multicolumn{2}{|c|}{ Port Hills $(1.10 .75)$} & \multicolumn{2}{|c|}{ Hunua (18.10.77) } \\
\hline & $3 \mathrm{~kg}$ & $15 \mathrm{~kg}$ & $5 \mathrm{~kg}$ & $10 \mathrm{~kg}$ \\
\hline Wairau & $3.0 \mathrm{c}$ & $8.3 \mathrm{a}$ & $3.0 \mathrm{c}$ & $8.5 \mathrm{a}$ \\
\hline College Glutinosa & $3.3 \mathrm{c}$ & 8.7 a & $5.0 \mathrm{~b}$ & $8.5 \mathrm{a}$ \\
\hline Rambler hybrid & $1.7 \mathrm{~d}$ & $7.0 \mathrm{~b}$ & $2.5 \mathrm{c}$ & $5.0 \mathrm{~b}$ \\
\hline
\end{tabular}

These differences in establishment and subsequent ground cover were reflected in dry matter production. At the Port Hills, crown diameter was measured in early spring 1975 , after selecting 10 plants at random from each plot. Following this, three $0.5 \mathrm{~m}^{2}$ quadrats were cut per plot on 12 November 1975 for spring diry matter determinations. These data are presented in Table 5.

TABLE 5: CROWN DIAMETER AND SPRING DRY MATTER YIELDS OF 3-YEAR-OLD LUCERNE CULTIVARS OVERSOWN ON THE PORT HILLS AT TWO RATES

\begin{tabular}{|c|c|c|c|c|c|}
\hline \multirow[b]{2}{*}{ Cultivar } & \multirow[b]{2}{*}{$\begin{array}{l}\text { crown } \\
\text { Diametes } \\
\text { (cm) }\end{array}$} & \multicolumn{2}{|c|}{$3 \mathrm{~kg} / \mathrm{ha}$} & $15 \mathrm{~kg} / \mathrm{ha}$ & \multirow[b]{2}{*}{$\begin{array}{l}\text { Percent- } \\
\text { age } \\
\text { Lucerne }\end{array}$} \\
\hline & & $\begin{array}{c}\text { Lucerne } \\
\text { DM (kg/ha) }\end{array}$ & $\begin{array}{l}\text { Percent- } \\
\text { age } \\
\text { Lucerne }\end{array}$ & $\begin{array}{l}\text { Lucerne } \\
\text { DM (kg/ha) }\end{array}$ & \\
\hline Wairau & 12.7 & $1120 \mathrm{~d}$ & 27 & $3340 \mathrm{a}$ & 56 \\
\hline College Glutinosa & 22.3 & $1750 \mathrm{c}$ & 39 & 4000 a & 63 \\
\hline Rambler hybrid & 28.0 & 620 e & 17 & $2270 \mathrm{~b}$ & 41 \\
\hline
\end{tabular}


These two experiments show that the best lucerne cultivar to use for oversowing is College Glutinosa. Its establishment and production was at least as good as Wairau, while it developed a large creeping crown within 3 years. Although College Glutinosa is susceptible to bacterial wilt and stem nematode, these have not been a great problem on dry hill country. Aphids have been recorded in the trials, but not in high numbers.

These experiments have shown that a seeding rate of 10 to $15 \mathrm{~kg} / \mathrm{ha}$ will produce 20 to 30 nodulated plants $/ \mathrm{m}^{2}$, which is almost as high as the optimum population of 30 plants $/ \mathrm{m}^{2}$ for hay stands suggested by Palmer and Wynn-Williams (1976).

\section{LuCERNE OvERSOWING}

As the practicability of oversowing lucerne on a large scale had not been assessed, a block of 2.5 ha was selected at Hunua which included steep slopes, a dry stony ridge, matagouri thickets and a sheep camp. Vegetation was sprayed by helicopter on 10 June 1977, using the same herbicide mixture as in previous trials. A topdressing of $160 \mathrm{~kg} / \mathrm{ha}$ of sulphur superphosphate was applied at the same time. A mixture of $15 \mathrm{~kg} / \mathrm{ha}$ of heavily inoculated lime pelleted College Glutinosa lucerne and $2.8 \mathrm{~kg} / \mathrm{ha}$ of Grasslands K1950 cocksfoot was oversown on 8 August. Conditions for establishment were ideal, with $100 \mathrm{~mm}$ of rain in August and $123 \mathrm{~mm}$ in September. Table 6 shows early establishment and survival after the summer drought at seven monitored sites, The figures show very high populations surviving after 9 months.

Two problems have been observed with the techniques used. The first is grass grubs (Odontria, Costyletra, etc.), which sometimes occur under the original vegetation before spraying and may survive to attack seedling lucerne and cocksfoot. The second problem is weeds. Sorrel is resistant to most herbicides and may

TABLE 6: ESTABLISHMENT OF LUCERNE AND COCKSFOOT FROM LARGE-SCALE OVERSOWING AT HLJNUA (plants/m?)

\begin{tabular}{lcc}
\hline \multicolumn{2}{c}{ Dafe of Sampling } & 15.5 .78 \\
\hline Species & $\mathbf{1 8 . 1 0 . 7 7}$ & \\
Mean & $\mathbf{1 0 6}$ & $\mathbf{4 4}$ \\
Range, 7 sites & $\mathbf{7 0 - 1 6 4}$ & $\mathbf{2 5 - 6 8}$ \\
Cocksfoot & $\mathbf{3 0}$ & 17 \\
Mean & $\mathbf{8 - 7 2}$ & $1-46$ \\
Range, 7 sites & & \\
\hline
\end{tabular}


compete strongly with oversown seedlings, while the bare ground following the spraying provides an ideal seedbed for spring germination of thistles (Carduus tenuifloris), flannel leaf (Verbascum thapsus), and barley grass (Hordeum murinum). However, the weed problem largely disappears after about 12 months of rotational grazing.

\section{GENERAL DISCUSSION AND CONCLUSIONS}

The improvement of pastures on dry northerly aspects by species introduction will continue to be difficult because of the severe and variable climatic conditions. The best clover species to use is undoubtedly subterranean, which, because of its annual habit, can survive severe droughts. Two factors, a high seed set and good autumn establishment, are keys to its success. At Hunua the early onset of drought reduces seed set in Woogenellup, and M. L. Smetham of the Plant Science Department is testing earlier flowering strains of subterranean clover for improved seeding. Initial establishment in autumn can be enhanced considerably by a high seeding rate, and a minimum of $9 \mathrm{~kg} / \mathrm{ha}$ should be sown (M. L. Smetham, pers. comm.) . Pastures should be grazed in late summer to remove any vegetation which may shade the germinating seed, but once a good germination has occurred, sheep should be removed until seedlings are well past the cotyledon stage, Close grazing when cotyledons are present will kill many plants. Our work suggests that some form of rotational grazing with reasonably long spelling periods would be the best grazing management for high production,

The only perennial clover worth sowing is white clover. Although it will not survive on steep dry slopes, there is always sufficient variation in aspect and moisture level to provide some sites suitable for it.

College Glutinosa lucerne has a place on sunny country even though the cost of establishment is much higher than that of clovers. Our early work (White 1970), the trials by Musgrave and Lowther (1976) at Omarama, and our present research all point to a number of key factors if establishment is to succeed. These are:

1. The selection of soils with a $\mathrm{pH}>5.6$, and preferably $>6.0$.

2. The use of herbicides where thick danthonia occurs, because of toxin problems affecting nodulation (Janson and White, 1971). 
3. The sowing of 10 to $15 \mathrm{~kg} / \mathrm{ha}$ of heavily inoculated lime pelleted seed.

4. Applying seed in the key period of early August when the soil is damp and moist conditions will continue for several weeks.

We envisage that lucerne would not be widely used, but would be sown in a few small blocks and carefully managed by rotational grazing. It would provide high quality feed in late spring and summer when growth of subterranean clover has ceased, and could be invaluable for weaned lambs.

A winter-active Mediterranean hybrid cocksfoot such as Grasslands K1950, with either subterranean clover or lucerne, shows much greater promise than the standard Apanui cocksfoot or Ruanui ryegrass, which do not persist well in this dry environment. Work by Jackson (1977) at Hunua showed that swards of K1950 cocksfoot and lucerne were compatible, and the cocksfoot was reasonably productive in good fertility conditions. With careful establishment techniques and good grazing management these legume and grass species will take maximum advantage of moisture in the cool season to produce good yields of dry matter, yet still survive the severe summer droughts which prevail on these sunny aspects.

\section{ACKN OWLEDGEMENTS}

We wish to thank Miss J. E. Radcliffe of MAF for considerable assistance with grass introduction experiments, and Mr B. Elder, "Mt. Vernon", Cashmere, and Mr W. McHugh, Hunua, for grazing management. Mr G. Bennett of Coated Seeds Ltd supplied all the inoculated pelleted lucerne seed.

\section{REFERENCES}

Jackson, S. H., 1977. A study of some factors affecting the growth of grasses introduced into hill pastures on sunny aspects in North Canterbury. M.Agr.Sc. thesis, Lincoln College; University of Canterbury.

Janson, C. G.; White, J. G. H., 1971. Lucerne establishment studies on uncultivated country. II. A nodulation problem. N.Z. Il agric. Res., 14: 587-96.

Musgrave, D. J.; Lowther, W. L., 1976, Effect of sowing date, inoculation level, and pelleting on the establishment of oversown lucerne. N.Z. Il exp. Agric., 4: 65-70.

Palmer, T. P.; Wynn-Williams, R. B., 1976. Relationship between. density and yield of lucerne. Ibid., 4: 65-70.

Radcliffe, J. E.; Johnstone, P. E.; Young, S. R., 1977. Survival and growth of introduced grasses in Canterbury hill country. Ibid., 5: 12935 . 
White, J. G. H., 1970. Establishment of lucerne (Medicago sativa L.) in uncultivated country by sodseeding and oversowing. Proc. XI int. Grassld Congr. : 134-S.

White, J. G. H.; Meijer, G.; Douglas, J. A., 1975. College Glutinosa lucerne. Proc. N.Z. Grassld Ass., 36: 173-9.

White, J. G. H.; Meijer, G.; Langer, R. H. M., 1972. Oversowing grasses on sunny and shady faces. Ibid., 34: 139-46. 